

\title{
Investigation of Sports Injuries and Kinesiophobia in Volleyball Players
}

\author{
Gülşah ÜNVER ${ }^{1 *}(D)$ \\ Ersan KARA ${ }^{2}$ \\ Atila YOLDAŞ ${ }^{3}$ \\ ${ }^{1}$ Kahramanmaraș Sütçü İmam Üniversitesi, Sağlık Bilimleri Fakültesi, KAHRAMANMARAȘ \\ ${ }^{2}$ Kırşehir Ahi Evran Üniversitesi, Beden Eğitimi ve Spor Yüksekokulu, KIRŞEHIR \\ ${ }^{3}$ Kahramanmaraş Sütçü İmam Üniversitesi, Tıp Fakültesi, KAHRAMANMARAŞ
}

\section{DOI: 10.31680/gaunjss.779513}

\section{Orijinal Makale / Original Article}

Geliș Tarihi / Received:12.08.2020
Kabul Tarihi / Accepted:09.11.2020

Yayın Tarihi / Published: 14.12 .2020

\begin{abstract}
Sports injuries are injuries that may occur due to individual or environmental factors, encountered during sports activities. The characteristics of sports injuries differ according to the sports branch. This study was carried out to determine musculoskeletal system injuries seen in volleyball players, to investigate kinesiophobia levels, to investigate the relationship between some personal information of athletes with injury and kinesiophobia. 102 athletes in the volleyball branch (61 female and 41 male) were included in the study. The injuries of the athletes were evaluated with the Musculoskeletal System Questionnaire. The kinesiophobia levels of the athletes were evaluated with the Tampa Kinesiophobia Scale. In addition, athletes filled in the personal information form, which included demographic information. SPSS 22 program was used to evaluate the data. The data were evaluated by $t$ test, anova test and chi-square test. Significance level was accepted as $p<0,05$. Among the athletes participating in the study, it was determined that 75 athletes experienced injuries in at least one region. As for the region, it was determined that the most injury was on the shoulder with a rate of $40,2 \%$. Some of the body parts where injuries are seen and some demographic information of the athletes differ statistically significantly. A significant correlation was found between gender and waist injuries, between gender and neck injuries, between athlete's position and waist injuries, between athlete's position and back injuries, between the number of weekly training and foot-ankle injuries $(p<0,05)$. Among the athletes who were exposed to injury, no significant difference was found in terms of the characteristics of the athletes and their kinesophobia values $(p>0,05)$.
\end{abstract}

Keywords: Volleyball, sports injury, kinesiophobia 
Ünver, G., Kara, E. ve Yoldaş, A. (2020). Investigation of Sports Injuries and Kinesiophobia in Volleyball Players. Gaziantep Üniversitesi Spor Bilimleri Dergisi, 5(4), 443- 455

\section{Introduction}

Sports injuries can occur due to intrinsic (individual personal) and extrinsic (environmental) factors encountered during sporting activities. Sports injuries are seen as a result of a certain part of the body or the whole body encountering more force than normal. Resistance limits of tissues are exceeded in sports injuries (Alagöz İmren, 2010). Sports injuries occur with different degrees of loading and strain on body structures and systems during sports activities (Ergun and Baltacı, 2018). Sports injuries require medical advice and/or treatment. Sports-related injuries cause a decrease in the level and dose of sports activity, and also have negative social and economic effects (Ergen, 1986).

Sports injuries are classified according to healing time, severity, mechanism of occurrence, type and location. Sports injuries are classified as mild injuries, moderate injuries, and serious injuries according to the healing time. Mild injuries are those that last 1-7 days. Moderate injuries are those that last 8-21 days. Serious injuries are those that last more than 21 days (Kanbir, 2005). Sports injuries are divided into subcategories according to their severity as less important, moderately important and very important. Less important are injuries such as skin abrasions, bruises, minor bumps that do not interfere with sports activities. Moderately important ones are sprain, strain etc. are injuries. The very important ones are major bone fractures, head injuries, abdominal trauma etc. that can be life-threatening are injuries (Demiröz, 2009). Sports injuries are divided into primary and secondary according to their formation mechanisms. Primary injuries are caused by direct stress. Secondary injuries, on the other hand, occur with the traumas that occur in previous injuries (Uluöz, 2007). Sports injuries are classified as soft tissue (muscle, tendon, ligament, bursa), bone tissue, joint, nerve, vessel, skin injuries according to their type (Ergun and Baltacı, 2018). Meanwhile sports injuries are also classified according to the body area where they are located. Sports injuries are specified according to the anatomical regions of the body in the classification according to localization (Hagglund et al., 2005). While examining the disturbances in the musculoskeletal system, the body can be divided into sections such as neck, shoulders, elbows, wrists / hands, back, waist, hips / thighs, knees, ankle / feet (Kahraman et al., 2016). Characteristics of injuries differ according to the sports branch.

Volleyball is an interval sport consisting of short-term loading and resting phases that require high muscle strength and ability, and includes anaerobic and 
Ünver, G., Kara, E. ve Yoldaş, A. (2020). Investigation of Sports Injuries and Kinesiophobia in Volleyball Players. Gaziantep Üniversitesi Spor Bilimleri Dergisi, 5(4), 443- 455

aerobic loads (Almeida and Soares, 2003; Sozen, 2012). Since the technical structure of the volleyball branch requires sudden and high power, athletes in this branch may encounter injuries (Uluöz, 2011). Jumping movements which are one of the movement patterns that are frequently used in volleyball defense (block, dunking service, dunking) and offensive require explosive power (Sheppard et al., 2007). Because of these features of the volleyball branch, especially the jumping movements from time to time exceeding the limits can cause injury to the athletes.

Kinesiophobia is a state of fear-avoidance of physical movement and activities due to the sensation of sensitivity to recurrent injury and painful injury (Kori et al., 1990; Burwinkle et al., 2005). Kinesiophobia can also be expressed as movement, activity, fear of re-injury or movement fear. In case of pain caused by sports injuries, fear, one of the psychological factors, can be seen. Fear may cause behaviors with escape and avoidance in response to previously experienced situations (Leeuw et al., 2007; Kaçoğlu et al., 2018). Kinesiophobia may occur in individuals with sports injuries. Kinesiophobia may adversely affect participation in treatment after sports injuries. Moreover, kinesophobia may negatively affect the rehabilitation process and the outcome of rehabilitation after sports injuries (Kvist et al., 2005). Athlete's perception of kinesiophobia may prevent achieving the expected athletic performance. Athlete's perception of kinesiophobia may cause delays in the return of the athlete to his sport and also may even cause the athlete to stop playing.

The aim of this study is to determine the musculoskeletal injuries and the characteristics of the injuries seen in volleyball players. It is also among the aims to examine the kinesophobia levels of athletes and to examine the relationship between injury and kinesophobia.

\section{Method}

\section{Research Group}

For this study, ethics committee approval was received from Kahramanmaras Sütcü Imam University Faculty of Medicine Clinical Research Ethics Committee (decision no:04, date:10.06.2020, session no:2020/11). 108 volleyball players who have been dealing with the volleyball branch for at least 1 year were reached for this study. It was determined that 6 of these athletes did not fill the questionnaires completely. Therefore, these 6 athletes were excluded from the study. So in this 
Ünver, G., Kara, E. ve Yoldaş, A. (2020). Investigation of Sports Injuries and Kinesiophobia in Volleyball Players. Gaziantep Üniversitesi Spor Bilimleri Dergisi, 5(4), 443- 455

study, 102 athletes in the volleyball branch (61 female and 41 male) were included in the study.

\section{Collection of Data}

The injuries of the athletes were evaluated with the Musculoskeletal System Questionnaire. Musculoskeletal System Questionnaire can be used for musculoskeletal system injuries. This survey includes features related to injuries. In this questionnaire, the body is divided into nine sections: neck, shoulder, elbow, hand-wrist, back, waist, hip-thigh, knee, foot-ankle. The characteristics of the injuries are specified separately for the regions. There are questions for each region in the questionnaire. These questions are whether the injury was observed, the type of injury, where the injury occurred, whether the injury was an obstacle to maintaining daily life, whether a health institution was consulted due to the injury, whether hospitalization for at least 1 day due to injury.

Athletes filled in the personal information form which included demographic information. This form had some information such as age, gender, height, body weight, faculty where the athlete is educated, athlete's sports year, being a national athlete, position in volleyball, weekly training number, average duration of the training. The information on this form was associated with injury characteristics.

The kinesiophobia levels of the volleyball players who had injuries were evaluated with the Tampa Kinesiophobia Scale. Turkish validity and reliability of the Tampa Kinesiophobia Scale was made by Yılmaz et al. Tampa Kinesiophobia Scale is a scale consisting of 17 questions used in health problems related to musculoskeletal system (Yılmaz et al., 2011). The Tampa Kinesiophobia Scale uses a 4-point Likert scoring system ( $1=$ Strongly disagree, $2=$ Agree, $3=$ Disagree, 4 = Totally agree) for each question. According to the answers of the participants, the total score takes a value between 17-68. A high score on this scale means that kinesiophobia is also high (Swinkels-Meewisse, 2003).

\section{Analysis of Data}

SPSS 22 program was used to evaluate the data. Frequency, percentage distribution, standard deviation and mean values were calculated. The data were analyzed by t-test, anova, chi-square tests. The knowledge of the participants and 
Ünver, G., Kara, E. ve Yoldaş, A. (2020). Investigation of Sports Injuries and Kinesiophobia in Volleyball Players. Gaziantep Üniversitesi Spor Bilimleri Dergisi, 5(4), 443- 455

the characteristics of their injuries were evaluated by chi-square test. Significance level was accepted as $p<0,05$.

\section{Results}

102 volleyball players (41 men, 61 women) were included in the study. While $50(49 \%)$ of the 102 people participating in the study are studying in the faculty of sports sciences, 52 people (51\%) are studying in other faculties. Among the participants, 13 people $(12,7 \%)$ are setter, 39 people $(38,2 \%)$ are hitter, 15 people $(14,7 \%)$ are libero, 23 people (22,5\%) are middle blocker, 12 people (11\%) are setter's diagonal. Among the participants, 2 people (2\%) are national athletes. Participants' sports years were grouped as 1-3 years, 4-6 years, 7-8 years, 9 years and more. The sports year of 15 people $(14,7 \%)$ is between 1-3 years. The sports year of 23 people $(22,5 \%)$ is between 4-6 years. The sports year of 25 people $(24,5 \%)$ is $7-8$ years. The number of participants whose sports year is 9 years or more are 39 people $(38,2 \%)$. The number of weekly trainings are grouped as $1-2$, $3-4,5$ and above. The number of weekly training of 28 people $(27,5 \%)$ is $1-2$. The number of weekly training of 54 people $(52,9 \%)$ is $3-4$. The number of participants with 5 or more weekly training are 20 people (19,6\%). The findings regarding the injuries of the participants are shown in the tables below in 9 sections.

Table 1. According to the Parts of the Body; Being Injured, Injury Type, Where the Injury Occurs

\begin{tabular}{|c|c|c|c|}
\hline Injury Area & Being Injured & Injury Type (Most Seen) & Where the Injury Occurs \\
\hline Neck & $14(13,7 \%)$ & $\begin{array}{c}\text { Strain: } 10(71,4 \%) \\
\text { Muscle pain: } 3(21,4 \%) \\
\text { Muscle cramp: } 1(7,1 \%)\end{array}$ & $\begin{array}{c}\text { In training: } 7(50 \%) \\
\text { In competition: } 3(21,4 \%) \\
\text { Other: } 4(28,6 \%)\end{array}$ \\
\hline Shoulder & $41(40,2 \%)$ & $\begin{array}{c}\text { Crushing-bruising: } 1(2,4 \%) \\
\text { Strain: } 13(31,7 \%) \\
\text { Muscle pain: } 12(29,3 \%) \\
\text { Muscle cramps: } 3(7,3 \%) \\
\text { Muscle tear: } 8(19,5 \%) \\
\text { Other: } 4(9,8 \%)\end{array}$ & $\begin{array}{c}\text { In training: } 29(70,7 \%) \\
\text { In competition: } 10(24,4 \%) \\
\text { Other: } 2(4,9 \%)\end{array}$ \\
\hline Elbow & $2(2 \%)$ & $\begin{array}{c}\text { Crushing-bruising: } 1(50 \%) \\
\text { Strain: } 1(50 \%)\end{array}$ & $\begin{array}{c}\text { In training: } 1(50 \%) \\
\text { In the competition: } 0(0 \%) \\
\text { Other: } 1(50 \%)\end{array}$ \\
\hline Hand-Wrist & $6(5,8 \%)$ & $\begin{array}{c}\text { Crushing-bruising: } 2(33,3 \%) \\
\text { Strain: } 2(33,3 \%) \\
\text { Sprain: } 1(16,7 \%) \\
\text { Other: } 1(16,7 \%)\end{array}$ & $\begin{array}{c}\text { In training: } 4(66,7 \%) \\
\text { In competition: } 2(33,3 \%) \\
\text { Other: } 0(0 \%)\end{array}$ \\
\hline Back & $18(17,6 \%)$ & $\begin{array}{c}\text { Strain: } 6(33,3 \%) \\
\text { Muscle pain: } 8(44,4 \%) \\
\text { Other: } 4(22,2 \%)\end{array}$ & $\begin{array}{c}\text { In training: } 11(61,1 \%) \\
\text { In competition: } 4(22,2 \%) \\
\text { Other: } 3(16,7 \%)\end{array}$ \\
\hline
\end{tabular}


Ünver, G., Kara, E. ve Yoldaş, A. (2020). Investigation of Sports Injuries and Kinesiophobia in Volleyball Players. Gaziantep Üniversitesi Spor Bilimleri Dergisi, 5(4), 443- 455

\begin{tabular}{|c|c|c|c|}
\hline Waist & $23(22,5 \%)$ & $\begin{array}{c}\text { Crushing-bruising: } 1(4,3 \%) \\
\text { Strain: } 10(43,5 \%) \\
\text { Muscle pain: } 5(21,7 \%) \\
\text { Fracture: } 1(4,3 \%) \\
\text { Other: } 6(26,1 \%)\end{array}$ & $\begin{array}{l}\text { In training: } 11(47,8 \%) \\
\text { In competition: } 6(26,1 \%) \\
\text { Other: } 6(26,1 \%)\end{array}$ \\
\hline Hip-Thigh & $2(2 \%)$ & $\begin{array}{l}\text { Crushing-bruising: } 1(50 \%) \\
\text { Muscle cramp: } 1(50 \%)\end{array}$ & $\begin{array}{l}\text { In training: } 1(50 \%) \\
\text { In competition: } 0(0 \%) \\
\text { Other: } 1(50 \%)\end{array}$ \\
\hline Knee & $17(16,6 \%)$ & $\begin{array}{c}\text { Crushing-bruising: } 9(52,9 \%) \\
\text { Strain: } 4(23,5 \%) \\
\text { Muscle pain: } 3(17,6 \%) \\
\text { Other (Cross ligament } \\
\text { rupture): } 1(5,9 \%)\end{array}$ & $\begin{array}{l}\text { In training: } 11(64,7 \%) \\
\text { In competition: } 4(23,5 \%) \\
\text { Other: } 2(11,8 \%)\end{array}$ \\
\hline Foot-Ankle & $26(25,4 \%)$ & $\begin{array}{c}\text { Strain: } 4(15,4 \%) \\
\text { Muscle pain: } 1(3,8 \%) \\
\text { Muscle cramp: } 1(3,8 \%) \\
\text { Muscle rupture: } 4(15,4 \%) \\
\text { Buckling: } 13(50 \%) \\
\text { Fracture: } 1(3,8 \%) \\
\text { Other: } 2(7,7 \%)\end{array}$ & $\begin{array}{c}\text { In training: } 15(57.7 \%) \\
\text { In competition: } 10(38,5 \%) \\
\text { Other: } 1(3,8 \%)\end{array}$ \\
\hline
\end{tabular}

Table 1 indicates the number of injured participants by region. In addition, the type of injuries of the injured participants and where the injury occurred are also indicated in this table. Among the athletes participating in the study, 75 athletes stated that they encountered injuries in at least one region. It was stated that the most injury was seen on the shoulder with a rate of $40,2 \%$. The most common type of injury is neck strain $(71,4 \%)$, shoulder strain $(31,7 \%)$, waist strain $(43,5 \%)$, back muscle pain $(44,4 \%)$, knee crushing-bruising (52,9\%), foot-ankle sprain (50\%). Most injuries occurred during training.

Table 2. According to the Parts of the Body; Prevention of Daily Life Due to Injury, Applying to the Health Institution Due to Injury, Hospital Stay for at Least 1 Day Due to Injury

\begin{tabular}{cccc}
\hline Injury Area & $\begin{array}{c}\text { Prevention of Daily } \\
\text { Life Due to Injury (At } \\
\text { Home or Outside) }\end{array}$ & $\begin{array}{c}\text { Applying to the Health } \\
\text { Institution Due to Injury }\end{array}$ & $\begin{array}{c}\text { Hospital Stay for at } \\
\text { Least 1 Day Due to } \\
\text { Injury }\end{array}$ \\
\hline Neck & $2(14,3 \%)$ & $2(14,3 \%)$ & $0(0 \%)$ \\
\hline Shoulder & $11(26,8 \%)$ & $15(63,4 \%)$ & $0(0 \%)$ \\
\hline Elbow & $2(100 \%)$ & $2(100 \%)$ & $0(0 \%)$ \\
\hline Hand-Wrist & $4(66,7 \%)$ & $3(50 \%)$ & $0(0 \%)$ \\
\hline Back & $10(44,4 \%)$ & $4(22,2 \%)$ & $0(0 \%)$ \\
\hline Waist & $15(65,2 \%)$ & $11(47,8 \%)$ & $1(4,3 \%)$ \\
\hline Hip-Thigh & $0(0 \%)$ & $0(0 \%)$ & $0(0 \%)$ \\
\hline Knee & $9(52,9 \%)$ & $9(52,9 \%)$ & $1(5,9 \%)$ \\
\hline Foot-Ankle & $22(84,6 \%)$ & $16(61,5 \%)$ & $6(23,1 \%)$ \\
\hline
\end{tabular}


Ünver, G., Kara, E. ve Yoldaş, A. (2020). Investigation of Sports Injuries and Kinesiophobia in Volleyball Players. Gaziantep Üniversitesi Spor Bilimleri Dergisi, 5(4), 443- 455

Table 2 shows the number of participants whose injuries prevent daily life, the number of participants who applied to the health institution due to injury, and the number of participants who stayed at the hospital for at least 1 day. This evaluation was made among the participants who had injuries by region. The situation of preventing the maintenance of daily life at home or outside due to the injury was more common in the elbow area (100\%) injury as a percentage of the injured. The situation of applying to any health institution due to injury was also seen mostly in those with elbow injuries (100\%). Hospitalization for at least 1 day was seen mostly in foot-ankle area injuries (23,1\%).

Demographic information of the participants and their characteristics of injury status and injuries were associated. The information about the participants and all the features of their injuries were evaluated with the chi-square test. A significant relationship was found between gender and injury in the neck region $(p=0,003)$. Approximately $93 \%$ of those who have had a injury in the neck area are women and $7 \%$ are men. A significant relationship was found between gender and waist injury $(p=0,039)$. Women constituted the majority of those who suffered from waist injury. $77 \%$ of those with waist injury are women, $23 \%$ of those with waist injury are men. In other words, neck area and waist area injuries were seen more in women than men. There was a statistically significant relationship between the athlete's position in volleyball and waist injury $(p=0,036)$. Setter's diagonal and middle blocker suffered from waist injury at approximately $42 \%$ and 35\% respectively. These rates were found to be $18 \%$ in hitters and $27 \%$ in liberos. The lowest rate (15\%) was in the setters. Injuries in the waist region were more common in setter's diagonals and middle blockers. There was a significant correlation between the number of training sessions per week and foot-ankle injuries $(p=0,036)$. $40 \%$ of those who train 5 or more a week experienced and foot-ankle injury. In addition, 32\% of those who trained 3-4 times a week were exposed to foot-ankle injuries. This rate is $11 \%$ for those who train 1-2 per week. The rate was found to be lower in those who train less. This situation can be interpreted as the excessive load in training reflects more on the foot-ankle joint, causes deterioration in the stability of this area and creates a basis for injuries.

It was analyzed whether there is a significant relationship between the demographic information of the injured athletes and kinesiophobia. Tables and explanations for the analysis are given below. 
Ünver, G., Kara, E. ve Yoldaş, A. (2020). Investigation of Sports Injuries and Kinesiophobia in Volleyball Players. Gaziantep Üniversitesi Spor Bilimleri Dergisi, 5(4), 443- 455

Table 3. Mean Scores of Kinesiophobia According Gender, Faculty Where the Athlete is Educated, Being National Athlete

\begin{tabular}{|c|c|c|c|c|c|c|}
\hline Variables & $\begin{array}{l}\text { Levels of } \\
\text { Variables }\end{array}$ & $\mathbf{N}$ & Average & $\begin{array}{c}\text { Std. } \\
\text { deflection }\end{array}$ & $\mathbf{t}$ & $\mathbf{p}$ \\
\hline \multirow[b]{2}{*}{ Gender } & Male & 26 & 38,42 & 6,51 & \multirow[b]{2}{*}{1,432} & \multirow[b]{2}{*}{0,156} \\
\hline & Female & 49 & 36,33 & 5,77 & & \\
\hline \multirow{2}{*}{$\begin{array}{l}\text { Faculty } \\
\text { Where the } \\
\text { Athlete is } \\
\text { Educated }\end{array}$} & $\begin{array}{l}\text { Faculty of Sport } \\
\text { Sciences }\end{array}$ & 37 & 36,83 & 6,06 & \multirow{2}{*}{0,301} & \multirow{2}{*}{0,764} \\
\hline & Other Faculties & 38 & 37,26 & 6,16 & & \\
\hline \multirow{2}{*}{$\begin{array}{l}\text { Being } \\
\text { National } \\
\text { Athlete }\end{array}$} & National Athletes & 2 & 41,50 & 4,94 & \multirow[b]{2}{*}{1,049} & \multirow[b]{2}{*}{0,297} \\
\hline & $\begin{array}{l}\text { Non-national } \\
\text { Athletes }\end{array}$ & 73 & 36,93 & 6,08 & & \\
\hline
\end{tabular}

There was no significant difference between men and women $(p=0,156)$. Kinesophobia variable does not differ in terms of the faculty of the participants $(p=0,764)$. Kinesophobia variable does not differ in terms of being a national athlete $(p=0,297)$.

Table 4. Mean Scores of Kinesiophobia According Sport Years and Position in Volleyball

\begin{tabular}{|c|c|c|c|c|c|c|}
\hline Variables & Levels of Variables & $\mathbf{N}$ & Average & $\begin{array}{c}\text { Std. } \\
\text { deflection }\end{array}$ & $\mathbf{F}$ & $\mathbf{p}$ \\
\hline \multirow{4}{*}{ Sport Years } & $1-3$ & 11 & 37,09 & 3,81 & \multirow{4}{*}{0,150} & \multirow{4}{*}{0,929} \\
\hline & $4-6$ & 13 & 37,85 & 5,54 & & \\
\hline & $7-9$ & 19 & 36,37 & 6,26 & & \\
\hline & $9+$ & 32 & 37,13 & 6,95 & & \\
\hline \multirow{6}{*}{ Position in Volleyball } & Setter & 9 & 36,88 & 6,45 & \multirow{6}{*}{0,413} & \multirow{6}{*}{0,799} \\
\hline & Hitter & 27 & 37,40 & 6,31 & & \\
\hline & Libero & 11 & 37,27 & 4,96 & & \\
\hline & Middle blocker & 18 & 37,72 & 6,55 & & \\
\hline & Setter's diagonal & 10 & 34,80 & 6,01 & & \\
\hline & Total & 75 & 37,05 & 6,07 & & \\
\hline
\end{tabular}

According to the results of anova test, there was no significant difference between the levels of sports years in terms of kinesiophobia values $(p=0,929)$. There was no significant difference between the position levels of the athletes in volleyball in terms of kinesiophobia values $(p=0,799)$. In other words, no significant difference was found among athletes who had injuries in terms of athletes' characteristics and kinesiophobia values.

\section{Discussion and Conclusion}

Augustsson et al. found the most common injuries to be ankle sprain (23\%) and knee joint injuries (18\%) in their study on Swedish volleyball players (Augustsson 
Ünver, G., Kara, E. ve Yoldaş, A. (2020). Investigation of Sports Injuries and Kinesiophobia in Volleyball Players. Gaziantep Üniversitesi Spor Bilimleri Dergisi, 5(4), 443- 455

et al., 2006). Can et al. determined in their study that the most injured area in volleyball was the foot and ankle (20,00\%). They determined that the shoulder area $(17,64 \%)$ is in the second place (Can et al., 2003). Knobloch et al. reported that the injuries encountered in volleyball are $71,3 \%$ in the upper extremity, $21,5 \%$ in the lower extremity, 4,3\% in the head area (Knobloch, 2004). The results of these studies are in some ways similar to the results of our study. Because the areas where the most injuries were seen in volleyball players are the shoulder area $(40,2 \%)$ and the ankle area $(25,4 \%)$ in our study.

Özgür et al. studied the frequency of sports injuries in volleyball and football players. Özgür et al. concluded in their study that the most common types of injury in volleyball players and football players were sprain (38,5\%), muscle and tendon ruptures (32,7\%) (Özgür et al., 2016). Bavlı conducted a study to determine the injuries faced by female volleyball players playing elite volleyball and the factors causing these injuries. It has been determined that athletes suffer from sprains mostly (Bavlı, 2013). While these results were in parallel with some aspects of our study, they were'nt similar in terms of some results. In our study, the injury in the type of sprain was most common in the foot-ankle (50\%). In other regions, the rates of different types of injuries were higher. These rates were as follows: neck strain $(71,4 \%)$, shoulder strain $(31,7 \%)$, waist strain $(43,5 \%)$, back muscle pain $(44,4 \%)$, knee crushing-bruising (52,9\%).

Bavlı stated in his study that volleyball players were exposed to injury most $(69,5 \%)$ during training (Bavlı, 2013). This result is similar to the results of our study. In our study, it was concluded that injuries are more common in training. In his study, Uluöz determined that $53,3 \%$ of the injuries in female volleyball players in the 16-22 age group occurred during the competition and 46,7\% during training (Uluöz, 2007). Özgür et al. found that sports injuries occur most frequently in volleyball players during competition (Özgür et al., 2016). In addition to studies showing similarities with our study in terms of seeing injuries in training or competition, there were also studies that differ from our study.

Kaçoğlu et al. reported in their study that depression and kinesophobia scores after sports injuries were not different between sports with and without physical contact (Kaçoğlu et al., 2018). Kinesophobia levels were evaluated according to the injury site in the studies of Goldberg et al. There was no significant difference in kinesiophobia scores between regions (Goldberg et al., 2018). In our study, the 
Ünver, G., Kara, E. ve Yoldaş, A. (2020). Investigation of Sports Injuries and Kinesiophobia in Volleyball Players. Gaziantep Üniversitesi Spor Bilimleri Dergisi, 5(4), 443- 455

relationship between athletes exposed to injuries and kinesophobia was examined. Among the injured athletes, no significant difference was found between the athletes' characteristics and their kinesophobia values. Medvecky and Nelson conducted a meta-analysis including 48 studies. They stated that $82 \%$ of the participants returned to some kind of sports activities. They also stated that $63 \%$ of the participants returned to their pre-injury level and $44 \%$ returned to competition sports. In this metaanalysis, it was also stated that kinesophobia was the most common cause of decreased or cessation of sport participation after the operatio (Medvecky and Nelson, 2015). When the literature is examined, it is understood that the results for kinesiophobia differ. It should be considered that kinesiophobia may also have an effect on returning to sports after injury. The reason athletes are unable to reach their sportive performance levels before injury is multifactorial. Fear of re-injury should be evaluated together with functional deficiencies.

Fear of re-injury should be evaluated together with functional deficiencies.For many active sports, it is not possible to completely eliminate the existing injury risks. Especially soft tissue injuries are inevitable in athletes. The repetitive and permanent characteristics of injuries that seem simple can be overlooked. Today, although precautions are taken, injuries can be seen in athletes. The type, region and severity of injuries vary according to the sports branch. Sports injuries affect athletes not only physically but also psychologically.

Volleyball branch allows individuals to develop in many ways. Volleyball branch is a branch that can be made easily by large masses. Tendency towards volleyball branch is high. Strong explosive power is required in volleyball especially for jump motion pattern. Due to this feature, sports injuries can be seen. In order to minimize sports injuries, measures should be taken at the individual, group and social level. These measures include medical control before the season, using materials to prevent injuries, adequate conditioning, appropriate warming and cooling, not using doping, proper nutrition, protective training, paying attention to hygiene conditions, fair play, preventive measures to protect the parties, establishing rules, acting in accordance with fair-play, informing about protective issues in sports (seminars, brochures, various publications), making legal regulations (such as anti-doping, material standardization, building features of facilities).

Rehabilitation is very important for returning to sports after injuries. Timely and correct rehabilitation is an important part of the treatment for athletes. Returning to 
Ünver, G., Kara, E. ve Yoldaş, A. (2020). Investigation of Sports Injuries and Kinesiophobia in Volleyball Players. Gaziantep Üniversitesi Spor Bilimleri Dergisi, 5(4), 443- 455

sports may be delayed or injury may recur due to insufficient participation in the rehabilitation program and not applying the necessary rehabilitation protocols. This situation may even result in the athlete leaving the sport completely. Returning to sports without full recovery may cause more serious injuries, and accordingly, it is important to ensure control with functional performance tests. It should be investigated that kinesophobia may have an effect on returning to sports after injury. In order to add the kinesiophobia approach to the rehabilitation programs, the factors causing kinesophobia should be determined. In this sense, the increase in the number of studies on the relationship between sports injuries and kinesophobia will contribute to the literature. It should be considered that the ability of athletes to reach their sportive performance levels before injury is multifactorial. Fear of re-injury should be examined together with functional deficiencies. The difference of athlete rehabilitation from general rehabilitation should be known. The full participation of functional rehabilitation in general rehabilitation protocols should be expanded. Athletes and sports experts should be informed in detail about the scope and importance of rehabilitation.

\section{References}

Alagöz İmren G. (2010). Review of The Opinion of The Sportsmen At High School Level on First Aid, Physical Therapy And Rehabilitation Applications In Kahramanmaraş Region. University of Kahramanmaraş Sütçü İmam, Institute of Health Sciences, Department of Physical Education and Sport, Ma thesis, Kahramanmaraş.

Almeida TA, Soares EA. (2003). Nutritional And Anthropometric Profile Of Adolescent Volleyball Athletes. Rev Bras Med Esporte, 9(4), 198-203.

Augustsson SR, Augustsson J, Thomeé R, Svantesson U. (2006). Injuries and

Preventive Actions In Elite Swedish Volleyball. Scandinavian Journal of Medicine \& Science in Sports, 16(6), 433-440.

Bavlı Ö. (2013). Investigation The Injury Patterns And Causes Of Elite Female Volleyball Players. International Refereed Academic Journal of Sports, Health and Medical Sciences, 3(7), 32-38.

Burwinkle T, Robinson JP, Turk DC. (2005). Fear Of Movement: Factor Structure of the Tampa Scale Of Kinesiophobia In Patients With Fibromyalgia Syndrome. J Pain, 6(6), 384-391. 
Ünver, G., Kara, E. ve Yoldaş, A. (2020). Investigation of Sports Injuries and Kinesiophobia in Volleyball Players. Gaziantep Üniversitesi Spor Bilimleri Dergisi, 5(4), 443- 455

Can S, Gürsoy R, Ezirmik N, Dane Ş. (2003). Sport Injuries In Students of Departments Of Physical Educatiuon And Sport. Gazi Journal of Physical Education and Sport Sciences, 8 (3), 59-64.

Demiröz MV. (2009). Evaluation Of Sport Facilities' Physical Features And Management Comprehension Owned By Provincial Directorate of Youth And Sports, In Terms Of Sportsmen And Trainers' Necessities And Expectations (Model As Kahramanmaraş City). University of Kahramanmaraş Sütçü İmam, Department of Physical Education and Sport, Institute of Social Science, Master thesis, Kahramanmaraş.

Ergen E. (1986). Spor Hekimliği, Sporda Sağlık Sorunları Ve Sakatlıklar, Ankara: Milli Eğitim Yayınevi.

Ergun N, Baltacı G. (2018). Spor Yaralanmalarında Fizyoterapi Ve Rehabilitasyon Prensipleri. 6. Baskı, Ankara: Hipokrat Kitabevi.

Goldberg P, Zeppieri G, Bialosky J, Bocchino C, van den Boogaard J, Tillman S, Chmielewski TL. (2018). Kinesiophobia And Its Association With HealthRelated Quality Of Life Across Injury Locations. Arch Phys Med Rehabil, 99 (1), 43-48.

Hagglund M, Walden M, Bahr R, Ekstrand J. (2005). Methods For Epidemiological Study Of Injuries To Professional Football Players: Developing The UEFA model. Br J Sports Med, 39 (6), 340-346.

Kaçoğlu C, Atalay E, Turhan B. (2018). Assessing The Kinesiophobia And Depression Status At Return To Sport Following Sport Related Injuries In Contact And Non-contact Sports. Turkish Journal of Sports Medicine, 53 (2), 67-75.

Kahraman T, Genç A, Göz E. (2016). The Nordic Musculoskeletal Questionnaire: Cross Cultural Adaptation Into Turkish Assessing Its Psychometric Properties. Disabil Rehabilitation, 38 (21), 2153-2160.

Kanbir O. (2005). Sporda Sağlık Bilinci ve İlkyardım. 2. Baskı. Bursa: Ekin Kitabevi, 21-24.

Knobloch K, Rossner D, Gössling T, Richter M, Krettek C. (2004). Volleyball Sport School Injuries. Sportverletz Sportschaden, 18 (4), 185-189.

Kori SH, Miller RP, Todd D. (1990). Kinesophobia: A New View Of Chronic Pain Behaviour. Pain Manag, 3, 35-43. 
Kvist J, Ek A, Sporrstedt K, Good L. (2005). Fear of Re-injury: A Hindrance For Returning To Sports After Anterior Cruciate Ligament Reconstruction. Knee Surg Sports Traumatol Arthrosc, 13(5), 393-397.

Leeuw M, Goossens MEJB, Linton SJ, Crombez G, Boersma K, Vlaeyen JWS. (2007). The Fear-Avoidance Model Of Musculoskeletal Pain: Current State Of Scientific Evidence. Journal of Behavioral Medicine, 30 (1), 77-94.

Medvecky MJ, Nelson S. (2015). Kinesiophobia and Return To Sports After Anterior Cruciate Ligament Reconstruction. Conn Med, 79 (3), 155-157.

Özgür B.O, Özgür T, Aksoy M. (2016). Sports Injury Frequency Of Volleyball And Football Players. Istanbul University Journal of Sport Science, 6 (3), 50-55.

Sheppard J, Newton R, Mcguigan M. (2007). The Effects of Accentuated Eccentric Load On Jump Kinetics In High-Performance Volleyball Players. International Journal of Sports Science \& Coaching, 2 (3), 267-273.

Sozen H. (2012). The Effect of Volleyball Training on the Physical Fitness of High School Students. Procedia-Social and Behavioral Sciences, 46, 1455-1460.

Swinkels-Meewisse EJCM, Swinkels RAHM, Verbeek ALM, Vlaeyen JWS, Oostendorp RAB. (2003). Psychometric Properties Of The Tampa Scale For Kinesiophobia And The Fear-Avoidance Beliefs Questionnaire In Acute Low Back Pain. Manual Ther, 8 (1), 29-36.

Tunca Yılmaz Ö, Yakut Y, Uygur F, Uluğ N. (2011). Turkish Version Of The Tampa Scale For Kinesiophobia And Its Test-Retest Reliability. Physiother Rehabil, 22 (1), 44-49.

Uluöz E. (2011). Investıgatıon of Physical, Antropometric And Somatotype Characteristic On Underelite Female Volleyball Players According To Playing Positions. e-Journal of New World Sciences Academy Sports Sciences, 6 (4), 206-213.

Uluöz E. (2007). Investigating Of Relation Between Injury Paterns With Hypermobility, Body Composition And Some Anthropometric Characteristics On 16-22 Ages Women Volleyball Players. Çukurova Unıversity, Institute of Health Sciences, Department of Physical Education and Sport, Ma thesis, Adana. 